\title{
Three-dimensional thermal sensitivity analysis of cooling of a magma chamber in the Los Azufres geothermal field, Michoacán, Mexico
}

\author{
Surendra P Verma ${ }^{1 *}$ and Efraín Gómez-Arias ${ }^{2}$
}

\author{
* Correspondence: spv@ier.unam.mx \\ ${ }^{1}$ Departamento de Sistemas \\ Energéticos, Instituto de Energías \\ Renovables, Universidad Nacional \\ Autónoma de México, Privada \\ Xochicalco s/n, Centro, Temixco, \\ Morelos 62580, Mexico \\ Full list of author information is \\ available at the end of the article
}

\begin{abstract}
Background: We present three-dimensional simulation of cooling of 63 models of a magma chamber in the Los Azufres geothermal field by varying the top of the chamber depth between 5 and $9 \mathrm{~km}$ (centroid from about 7 to $13 \mathrm{~km}$ ) and its volume between 300 and $600 \mathrm{~km}^{3}$.

Methods: Nineteen new best-fit cubic equations are presented to represent the temperature field in the geothermal reservoir in terms of the chamber centroid depth, its volume, or both.

Results: These equations clearly show that the thermal regime is much more sensitive to chamber depth than to its volume. These simulation results imply that, for a better estimation of the energy budget of a volcanic area, the depth parameter should be better constrained than the chamber volume.

Conclusion: Geoscientists are, therefore, encouraged to obtain more reliable estimates of magma chamber depths for active volcanoes and potential geothermal areas. Furthermore, the smallest discretization time and mesh size should be used for solving the heat flow equations in three-dimensions.
\end{abstract}

Keywords: Thermal modeling; Subsurface temperatures; Geothermal system; Magma chamber; Three-dimensional simulation

\section{Background}

Three-dimensional thermal modeling of a magma chamber has been already applied to decipher thermal regime beneath the Los Humeros and La Primavera geothermal fields, located in the eastern and western parts of the Mexican Volcanic Belt, respectively (LHGF and LPGF, respectively, in Figure 1; Verma and Andaverde 2007; Verma et al. 2012; Verma and Gómez-Arias 2013a). Such a three-dimensional model has been also put forth for cooling of two magma chambers in the Las Tres Vírgenes geothermal field, Baja California Sur, Mexico (Guerrero-Martínez and Verma 2013).

The sensitivity of two magma chamber parameters - chamber depth and volume was also evaluated by Verma et al. (2011) at the top of the magma chamber as well as at its sides, which indicated that the chamber depth is more sensitive than the chamber volume. Similarly, the influence of discretization time and mesh size was estimated from three-dimensional temperature field simulation in the LHGF and LPGF (Verma and Gómez-Arias 2013b).

(c) 2013 Verma and Gomez-Arias; licensee Springer. This is an Open Access article distributed under the terms of the Creative Commons Attribution License (http://creativecommons.org/licenses/by/2.0), which permits unrestricted use, distribution, and reproduction in any medium, provided the original work is properly cited. 


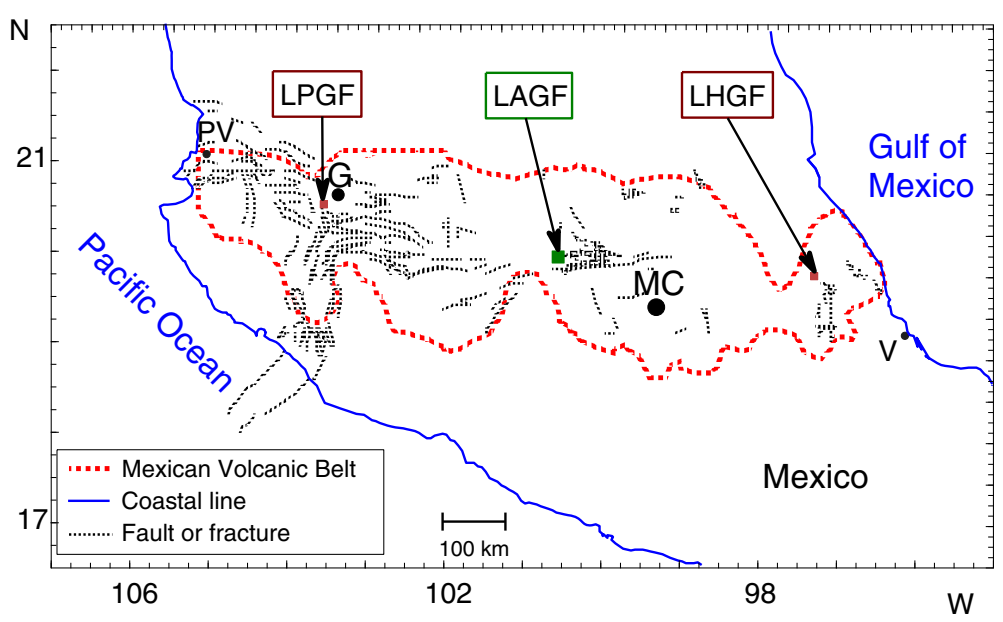

Figure 1 Location of the Los Azufres geothermal field (LAGF), Michoacán. The map was modified after Verma et al. (2012). LAGF, in the central part of the Mexican Volcanic Belt (MVB), LHGF, Los Humeros geothermal field, Puebla, eastern part of the MVB; LPGF, La Primavera geothermal field, Jalisco, western part of the MVB; PV, Puerto Vallarta; G, Guadalajara; MC, Mexico City; V, Veracruz.

For the Los Azufres geothermal field (LAGF in Figure 1) located in the central part of the Mexican Volcanic Belt, only two-dimensional thermal modeling was carried out long ago by Verma and Andaverde (1996). We present the first three-dimensional simulation study of this field and document the temperature regime in the underlying geothermal reservoir as a function of the chamber depth and volume. The reservoir temperatures are inferred to be much more sensitive to chamber depth than to its volume. This is the first study that evaluates the sensitivity of these two parameters for a geothermal reservoir. Six additional runs for the last thermal model are presented to predict the thermal regime of this geothermal area and to understand the influence of discretization time and mesh size.

\section{Geological synthesis}

The LAGF is located in the state of Michoacán, about $200 \mathrm{~km}$ NW of Mexico City, between approximately $100^{\circ} 38^{\prime}$ and $100^{\circ} 43^{\prime} \mathrm{W}$ and $19^{\circ} 50^{\prime}$ and $19^{\circ} 45^{\prime} \mathrm{N}$, and covers an area of about $72 \mathrm{~km}^{2}$ (Dobson and Mahood 1985). The geology and geochemistry of the area were reported by Campos-Enríquez et al. (2005), Cathelineau et al. (1987), Dobson and Mahood (1985), Pandarinath (2011), Pandarinath et al. (2008), Pradal and Robin (1994), Verma (1985), Verma and Andaverde (1996), and Verma et al. (2005), among others. The pre-volcanic basement consists of shales, sandstones, and conglomerates of Eocene to Oligocene age. The oldest volcanic rocks are andesites of Miocene age (about 18 to $6 \mathrm{Ma}$ ) followed by the eruption of rhyolites at 1.6 to $0.84 \mathrm{Ma}$ and andesites at about $0.86 \mathrm{Ma}$.

Voluminous eruption of dacites (about $19.3 \mathrm{~km}^{3}$ ) took place at about 0.36 to $0.33 \mathrm{Ma}$. This major event was simulated in our thermal modeling, which was carried out for about $0.40 \mathrm{Ma}$ to the present. This large eruption was followed by about $12.2 \mathrm{~km}^{3}$ of rhyolites during about 0.30 to $0.14 \mathrm{Ma}$ and about $4.6 \mathrm{~km}^{3}$ of the youngest basalt, considered to have erupted during $0.15 \mathrm{Ma}$ to the present. From geochemical 
modeling, Verma (1985) suggested that the volume of the magma chamber beneath the LAGF was at least about $400 \mathrm{~km}^{3}$.

\section{Methods}

\section{Conceptual models and methods}

A region of $30 \mathrm{~km}$ ( $x$-axis, north-south direction) $\times 30 \mathrm{~km}$ ( $y$-axis, east-west direction $) \times$ $20 \mathrm{~km}$ ( $z$-axis, vertical direction) was considered for 3-D simulator TCHEMSYS of Verma and Andaverde (2007). For thermal sensitivity analysis, uniform mesh size of $0.25 \mathrm{~km} \times$ $0.25 \mathrm{~km} \times 0.25 \mathrm{~km}$ was used, which resulted in $120 \times 120 \times 80$ control volumes (a total of $1,152,000$ volumes for solving heat-flow equations in three dimensions). Emplacement and boundary conditions as well as simplified geology are summarized in Table 1.

To evaluate the sensitivity of chamber depth and volume, 63 different simulation models were considered from nine chamber depths (top of the chamber at 5 to $9 \mathrm{~km}$, with increments of $0.5 \mathrm{~km}$ ) and seven chamber volumes (300 to $600 \mathrm{~km}^{3}$, with increments of $50 \mathrm{~km}^{3}$ ). All 63 models from M1 to M63 are summarized in Table 2. For example, the first nine models, M1, M2, M3, M4, M5, M6, M7, M8, and M9, correspond to the top of the magma chamber at the subsurface depths of 5.0, 5.5, 6.0, 6.5, 7.0, 7.5, $8.0,8.5$, and $9.0 \mathrm{~km}$, respectively, and the chamber volume of $300 \mathrm{~km}^{3}$ is for each of them. Three of these models, M1, M5, and M9, are graphically presented in Figure 2. Similarly, three of the final models, M55, M59, and M63, are shown in Figure 3. Discretization time of 500 years and total simulation time of 100,000 years were used for these 63 models. Cubic polynomial equations were fitted to the appropriate simulated results.

Similarly, six runs were carried out for discretization time of 20, 10, and 1 year, mesh size of 0.20 and $0.10 \mathrm{~km}$, and total simulation time of 0.40 million years representing the entire eruption history of the main volcanic events (Dobson and Mahood 1985; Verma and Andaverde 1996). These runs were obtained for $5 \mathrm{~km}$ depth of the top of magma chamber, $600 \mathrm{~km}^{3}$ of chamber volume, and three magma recharge events at $0.34 \mathrm{Ma}\left(20 \mathrm{~km}^{3}\right.$ of magma), $0.22 \mathrm{Ma}\left(12 \mathrm{~km}^{3}\right)$, and $0.026 \mathrm{Ma}\left(5 \mathrm{~km}^{3}\right)$. The magma chamber depth and volume for these runs correspond to the model M55 (Figure 3).

\section{Results and discussion}

\section{Evaluation of sensitivity of chamber depth and volume}

Temperature versus depth (or control volume number) profiles for the 63 simulated models were similar to the one presented in Figure 4 corresponding to model M55 (Table 2). The magma chamber is schematically shown by continued lines. The diagram shows the temperature distribution along a vertical line (coordinates 80, 1 in the control volume space) of $20 \mathrm{~km}$ depth, at the center of the chamber ( $x=60$ and $y=60$ ), i.e., between the surface $(x, y, z$ coordinates $60,60,80)$ and the deepest part of the simulated volume $(60,60,1)$. Note the thermal anomaly due to the emplacement and cooling of the magma chamber is still observed within the magma chamber, as well as both above and below it (compare filled diamonds and open squares with the normal geothermal gradient shown as a dotted line in Figure 4).

Figure 5 shows the results of simulated temperatures and temperature excess values (the difference of simulated temperatures and the normal subsurface temperatures) 


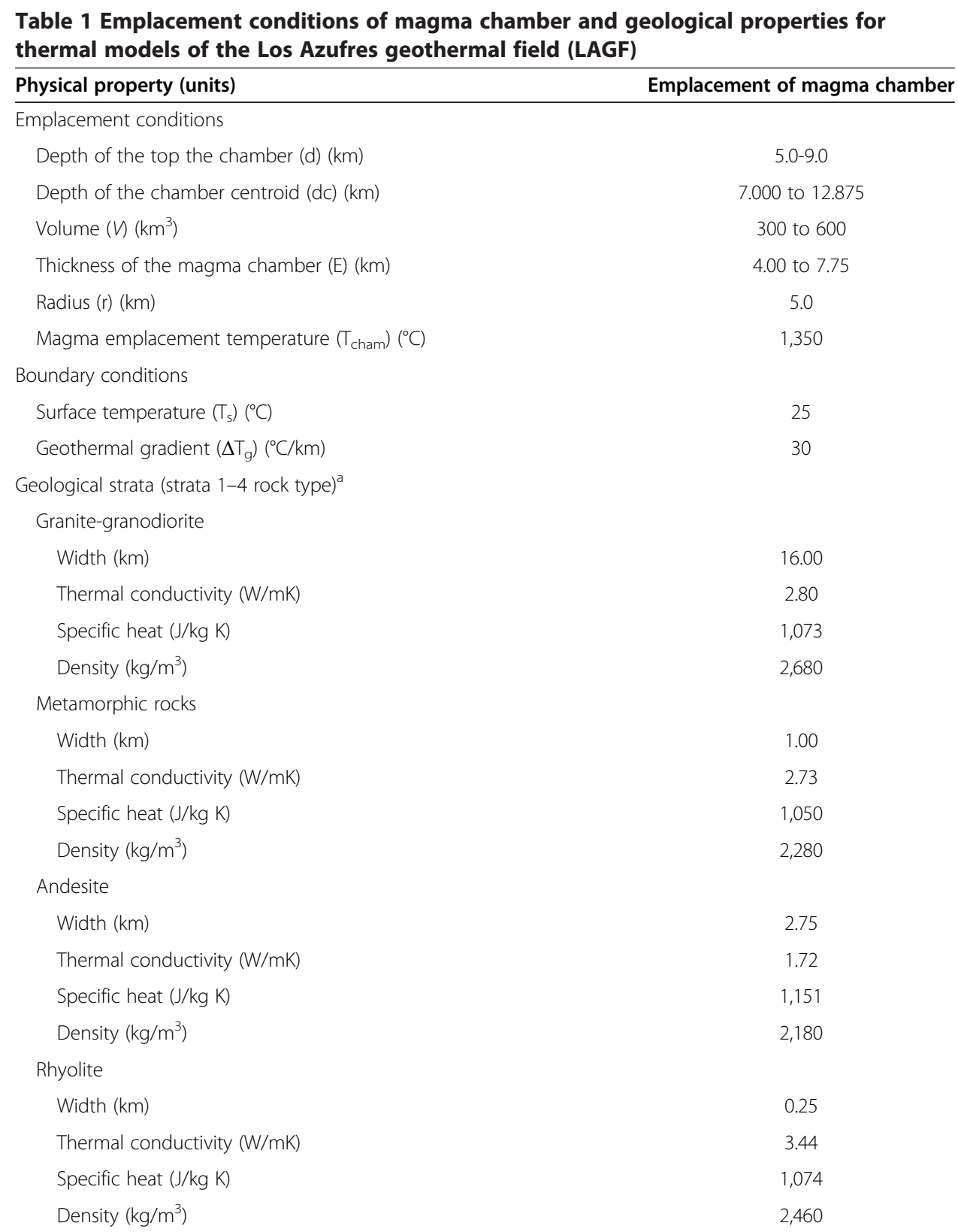

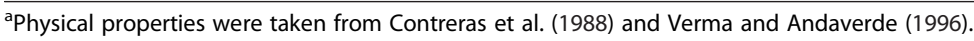

along a vertical profile at the middle part of the simulated region for the same model as in Figure 4 (M55; Table 2). From these estimates, vertical thermal gradient $(\delta T)$ values in the geothermal reservoir (subsurface depths of 1 to $2.5 \mathrm{~km}$ ) were estimated for all 63 models.

Best-fit cubic equations for the thermal gradient as a function of the depth of the chamber centroid (dc) parameter (Equations 1 to 7) are listed in Table 3. The results of the models used for a given equation are also listed in the third column of Table 3. As an example, Equation 1 was obtained from the simulated results of models M1 to M9 (Tables 2 and 3). Equation 1 shows the behavior of simulated thermal (note 'thermal' and not 'geothermal' is used, because we have subtracted the initial 'normal' geothermal temperatures from the simulated temperatures) gradient in the geothermal reservoir 
Table 2 Specifications of the 63 models of the Los Azufres geothermal field (LAGF) simulated in the present work

\begin{tabular}{|c|c|c|c|c|}
\hline \multirow[t]{2}{*}{ Model } & \multicolumn{2}{|c|}{ Subsurface depth } & \multirow{2}{*}{$\begin{array}{c}\text { Chamber } \\
\text { volume } V \\
\left(\mathrm{~km}^{3}\right)\end{array}$} & \multirow{2}{*}{$\begin{array}{l}\text { Thickness of } \\
\text { the magma } \\
\text { chamber } E(\mathrm{~km})\end{array}$} \\
\hline & Top of the chamber $\mathrm{d}(\mathrm{km})$ & Chamber centroid dc $(\mathbf{k m})$ & & \\
\hline M1 & 5.0 & 7.000 & 300 & 4.00 \\
\hline M2 & 5.5 & 7.500 & 300 & 4.00 \\
\hline M3 & 6.0 & 8.000 & 300 & 4.00 \\
\hline M4 & 6.5 & 8.500 & 300 & 4.00 \\
\hline M5 & 7.0 & 9.000 & 300 & 4.00 \\
\hline M6 & 7.5 & 9.500 & 300 & 4.00 \\
\hline M7 & 8.0 & 10.000 & 300 & 4.00 \\
\hline M8 & 8.5 & 10.500 & 300 & 4.00 \\
\hline M9 & 9.0 & 11.000 & 300 & 4.00 \\
\hline M10 & 5.0 & 7.250 & 350 & 4.50 \\
\hline M11 & 5.5 & 7.750 & 350 & 4.50 \\
\hline $\mathrm{M} 12$ & 6.0 & 8.500 & 350 & 4.50 \\
\hline M13 & 6.5 & 8.750 & 350 & 4.50 \\
\hline M14 & 7.0 & 9.250 & 350 & 4.50 \\
\hline M15 & 7.5 & 9.750 & 350 & 4.50 \\
\hline M16 & 8.0 & 10.250 & 350 & 4.50 \\
\hline M17 & 8.5 & 10.75 & 350 & 4.50 \\
\hline M18 & 9.0 & 11.250 & 350 & 4.50 \\
\hline M19 & 5.0 & 7.500 & 400 & 5.00 \\
\hline M20 & 5.5 & 8.000 & 400 & 5.00 \\
\hline M21 & 6.0 & 8.500 & 400 & 5.00 \\
\hline M22 & 6.5 & 9.000 & 400 & 5.00 \\
\hline M23 & 7.0 & 9.500 & 400 & 5.00 \\
\hline M24 & 7.5 & 10.000 & 400 & 5.00 \\
\hline M25 & 8.0 & 10.500 & 400 & 5.00 \\
\hline M26 & 8.5 & 11.000 & 400 & 5.00 \\
\hline M27 & 9.0 & 11.500 & 400 & 5.00 \\
\hline M28 & 5.0 & 7.875 & 450 & 5.75 \\
\hline M29 & 5.5 & 8.375 & 450 & 5.75 \\
\hline M30 & 6.0 & 8.875 & 450 & 5.75 \\
\hline M31 & 6.5 & 9.375 & 450 & 5.75 \\
\hline M32 & 7.0 & 9.875 & 450 & 5.75 \\
\hline M33 & 7.5 & 10.375 & 450 & 5.75 \\
\hline M34 & 8.0 & 10.875 & 450 & 5.75 \\
\hline M35 & 8.5 & 11.375 & 450 & 5.75 \\
\hline M36 & 9.0 & 11.875 & 450 & 5.75 \\
\hline M37 & 5.0 & 8.250 & 500 & 6.50 \\
\hline M38 & 5.5 & 8.750 & 500 & 6.50 \\
\hline M39 & 6.0 & 9.250 & 500 & 6.50 \\
\hline M40 & 6.5 & 9.750 & 500 & 6.50 \\
\hline M41 & 7.0 & 10.250 & 500 & 6.50 \\
\hline M42 & 7.5 & 10.750 & 500 & 6.50 \\
\hline
\end{tabular}


Table 2 Specifications of the 63 models of the Los Azufres geothermal field (LAGF) simulated in the present work (Continued)

\begin{tabular}{lllll}
\hline M43 & 8.0 & 11.250 & 500 & 6.50 \\
M44 & 8.5 & 11.750 & 500 & 6.50 \\
M45 & 9.0 & 12.250 & 500 & 6.50 \\
M46 & 8.500 & 550 & 7.00 \\
M47 & 5.0 & 9.000 & 550 & 7.00 \\
M48 & 5.5 & 9.500 & 550 & 7.00 \\
M49 & 10.000 & 550 & 7.00 \\
M50 & 6.0 & 10.500 & 550 & 7.00 \\
M51 & 6.5 & 11.000 & 550 & 7.00 \\
M52 & 11.500 & 550 & 7.00 \\
M53 & 7.0 & 12.000 & 550 & 7.00 \\
M54 & 7.5 & 12.500 & 550 & 7.00 \\
M55 & 8.0 & 8.875 & 600 & 7.75 \\
M56 & 8.5 & 9.375 & 600 & 7.75 \\
M57 & 9.0 & 9.875 & 600 & 7.75 \\
M58 & 5.0 & 10.375 & 600 & 7.75 \\
M59 & 5.5 & 10.875 & 600 & 7.75 \\
M60 & 6.0 & 11.375 & 600 & 7.75 \\
M61 & 6.5 & 11.875 & 600 & 7.75 \\
M62 & 7.0 & 12.375 & 600 & 7.75 \\
M63 & 7.5 & 12.875 & 600 & 7.75 \\
\hline
\end{tabular}

obtained from centroid depths of about 7.0 to $11.0 \mathrm{~km}$ and a fixed chamber volume of $300 \mathrm{~km}^{3}$. The quality of the cubic fit can be judged from the value of $R^{2}=0.999000$, which is statistically significant ( $>99 \%)$. Note that the maximum value of $R^{2}$ can be 1.00000. We note that for the linear correlation coefficient $(r)$ to be statistically meaningful (Verma et al. 2005), it should be reported as rounded to at least three (in fact, four or more) decimal places, because the critical value tables for different significance levels have values with up to three decimal places (Ebdon 1988; Bevington and Robinson 2003). The $R^{2}$, therefore, will have to be reported to at least five (in fact, more) decimal places; otherwise, it may be indistinguishable from the maximum value of 1 .

The values of the coefficients and the respective errors of the first term (without dc) and the three other terms $\left(\mathrm{dc}, \mathrm{dc}^{2}\right.$, and $\mathrm{dc}^{3}$ ) in Equation 1 are included. The statistically significant fit, quantitatively expressed in the $R^{2}$ parameter, is also indicated by relatively low errors of the coefficients in Equation 1. The values of the coefficients $\left(-498.9,49.76\right.$, and -1.653 , respectively, for $\mathrm{cd}, \mathrm{dc}^{2}$, and $\mathrm{dc}^{3}$; respective errors of 32.6, 3.66 , and 0.135 , equivalent to about $6.5 \%, 7.3 \%$, and $8.2 \%$, respectively) indicate the sensitivity of the dc variable. Similarly statistically valid results were obtained for the other equations (Equations 2 to 7; see $R^{2}$ values of 0.998990 to 0.998993 ). Note that had we reported rounded $R^{2}$ values to less number of decimal places, most of them will be indistinguishable from each other and from the maximum value of 1 . The differences among the errors of the coefficients in Equations 1 to 7 could not then be explained from small differences in the $R^{2}$ quality parameter (Table 3). 


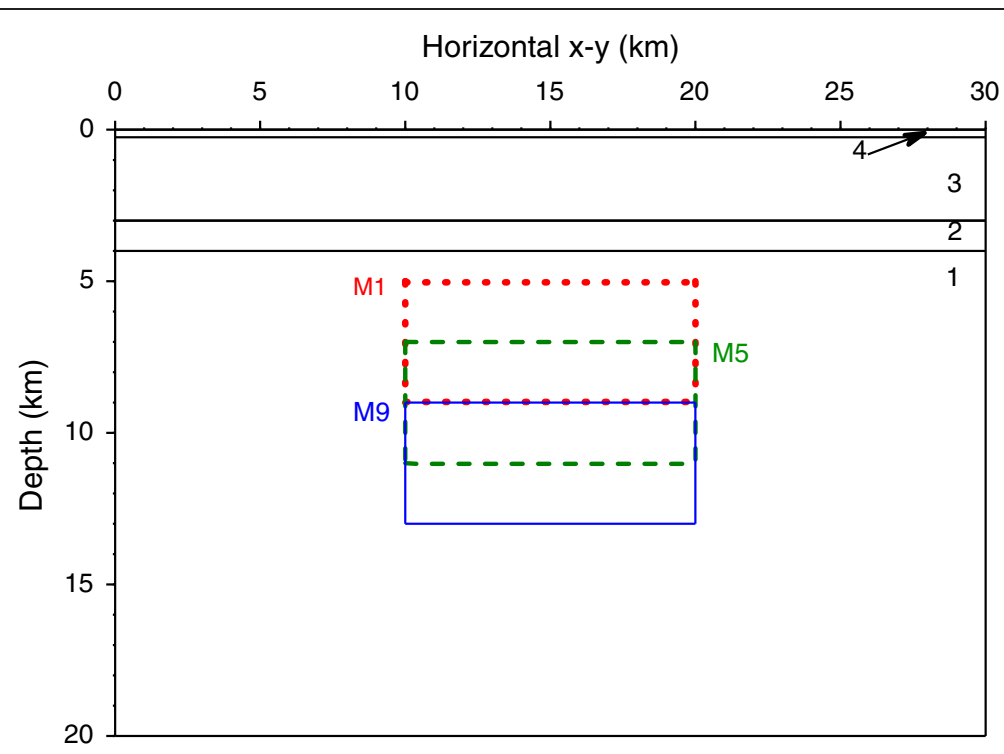

Figure 2 Simplified geological models (M1, M5, and M9) of the Los Azufres geothermal field (LAGF), Michoacán, Mexico. These models were input in the three-dimensional simulator TCHEMSYS. Numbers 1 to 4 are for geological strata (Table 1).

Equations 8 to 16 corresponding to the chamber volume $(V)$ parameter are presented in Table 4. All equations represent statistically significant cubic fit, because $R^{2}$ values are relatively high $(0.969720$ to 0.991220 ; confidence levels of $>99 \%)$. However, the values of the coefficients, particularly, for the $V, V^{2}$, and $V^{3}$ terms are much smaller than those for the respective dc terms (compare Equations 8 to 16 with 1 to 7 ). For example, in Equation 8 that represents the behavior of $\delta T$ as a function of $V$, the coefficients for $V, V^{2}$, and $V^{3}$ are, respectively, $5.80 \times 10^{-3}, 11.67 \times 10^{-3}$, and $7.69 \times 10^{-3}$, with respective errors of $0.90 \times 10^{-3}, 2.05 \times 10^{-3}$, and $1.52 \times 10^{-3}$, equivalent to about $15.5 \%$,

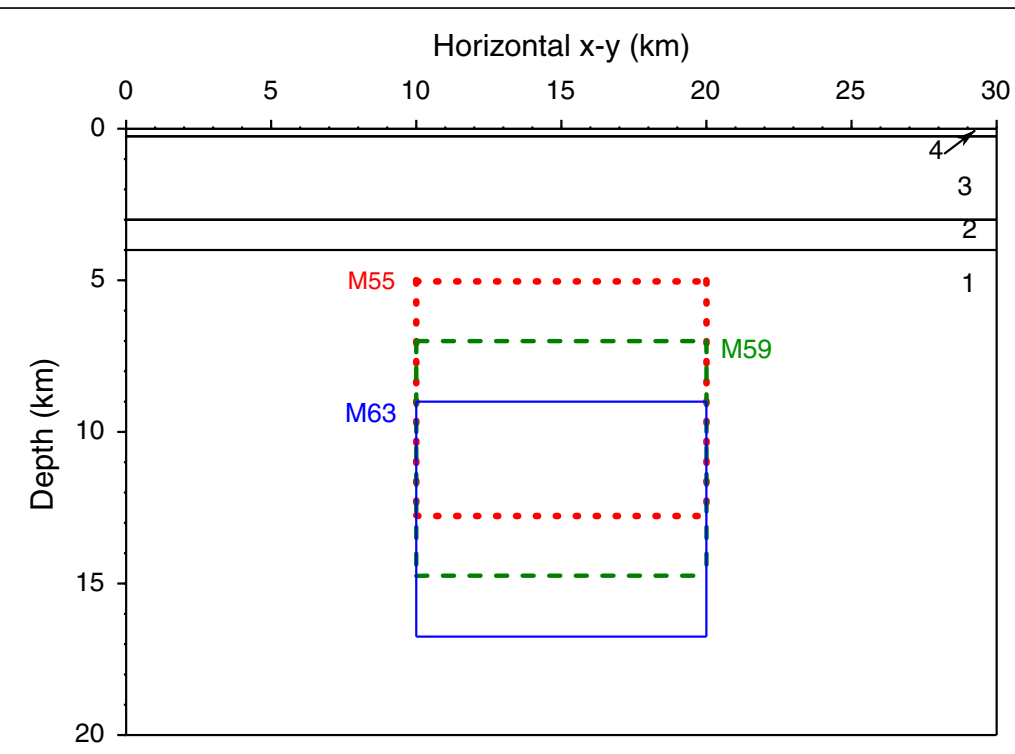

Figure 3 Simplified geological models (M55, M59, and M63) of the Los Azufres geothermal field (LAGF), Michoacán, Mexico. These models were input in the three-dimensional simulator TCHEMSYS. Numbers 1 to 4 are for geological strata (Table 1). 


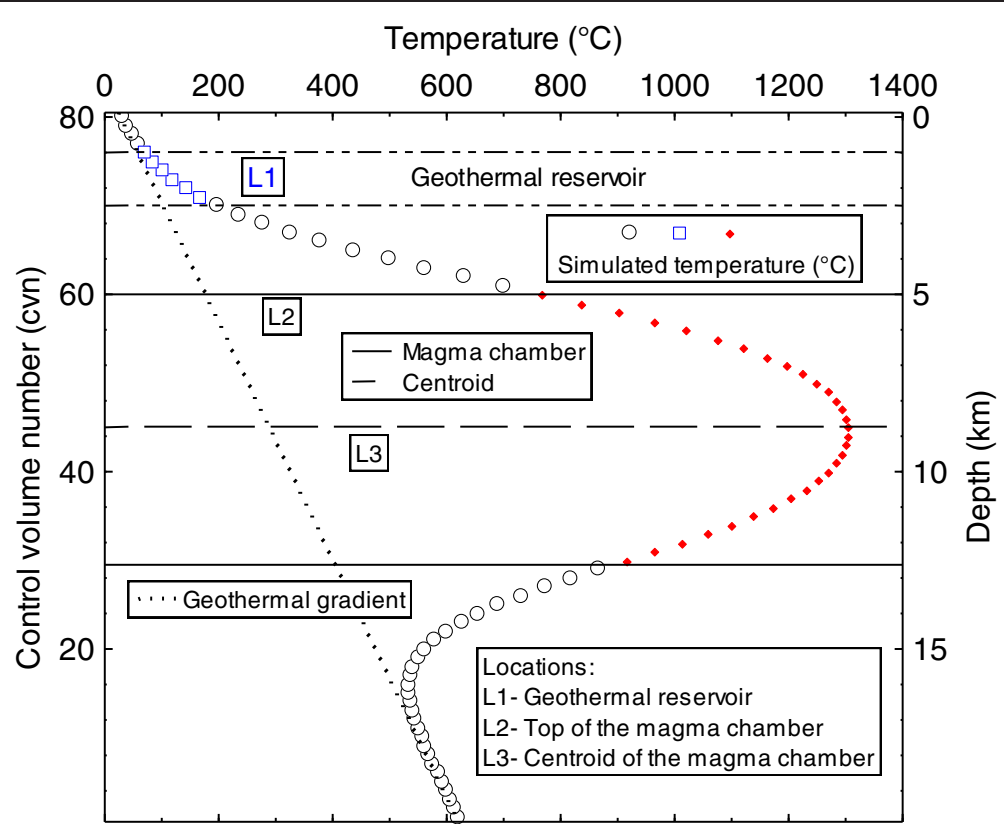

Figure 4 Temperature field distribution. Temperatures are reported as a function of the depth in $\mathrm{km}$ (vertical axis on the right side of the diagram) or as the number of control volumes (cvn; vertical axis at the left side of the diagram). The conditions of this model (M55; Table 2) are as follows: the top of the magma chamber at $5 \mathrm{~km}$ depth, chamber volume of $600 \mathrm{~km}^{3}$, and emplacement time of the 100,000 years ( $\delta t$ of 500 years).

$17.6 \%$, and $19.7 \%$, respectively. These mean values are much smaller than those for Equation 1 , whereas the respective errors are much greater $(15.5 \%$ to $19.7 \%$ for volume terms as compared to $6.5 \%$ to $8.2 \%$ for centroid depth terms). The same is true for all other equations of Tables 3 and 4. All these inferences are statistically valid as examined from significance tests through UDASYS software (Verma et al. 2013), which uses highly precise and accurate critical values (Cruz-Huicochea and Verma 2013; Verma and Cruz-Huicochea 2013). The errors of the coefficients of dc terms in Equations 1 to 7 vary from $6.5 \%$ to $8.2 \%$, whereas those for the $V$ terms in Equations 8 to 16 show the range of $15.5 \%$ to $27.8 \%$. The intercept terms, on the other hand, show higher percent errors for $\mathrm{dc}$ (5.7\% to $6.1 \%$ ) than for $V$ equations $(0.004 \%$ to $0.3 \%)$.

The coefficients of the linear dc term in Equations 1 to 7 range from about -500 to -700 , whereas those for the $V$ term vary from about $7.0 \times 10^{-3}$ to $5.8 \times 10^{-3}$. Similar relationship is valid for the quadratic and cubic terms (Tables 3 and 4). The relatively large values of the coefficients for the dc as compared to the $V$ parameter imply that for thermal gradient, the magma chamber depth is much more sensitive than the chamber volume.

In order to confirm the importance of chamber depth as compared to its volume, we used the results of all 63 simulations to obtain the final best-fit equations (Equations 17 to 19; Table 5). Although the $R^{2}$ value for the cubic fit for the dc parameter is relatively high (0.691799), the errors for all coefficients are much higher than the respective coefficient values (Equation 17). Equation 18 representing the thermal gradient as a function of chamber volume seems to be statistically meaningless (note the almost negligible value 0.000000 of $R^{2}$ and extremely large errors for all coefficients).

Therefore, using all 63 simulations, we present our best-fit Equation 19 for the thermal gradient as a function of both parameters (dc and $V$ ). The $R^{2}$ value of 0.838748 


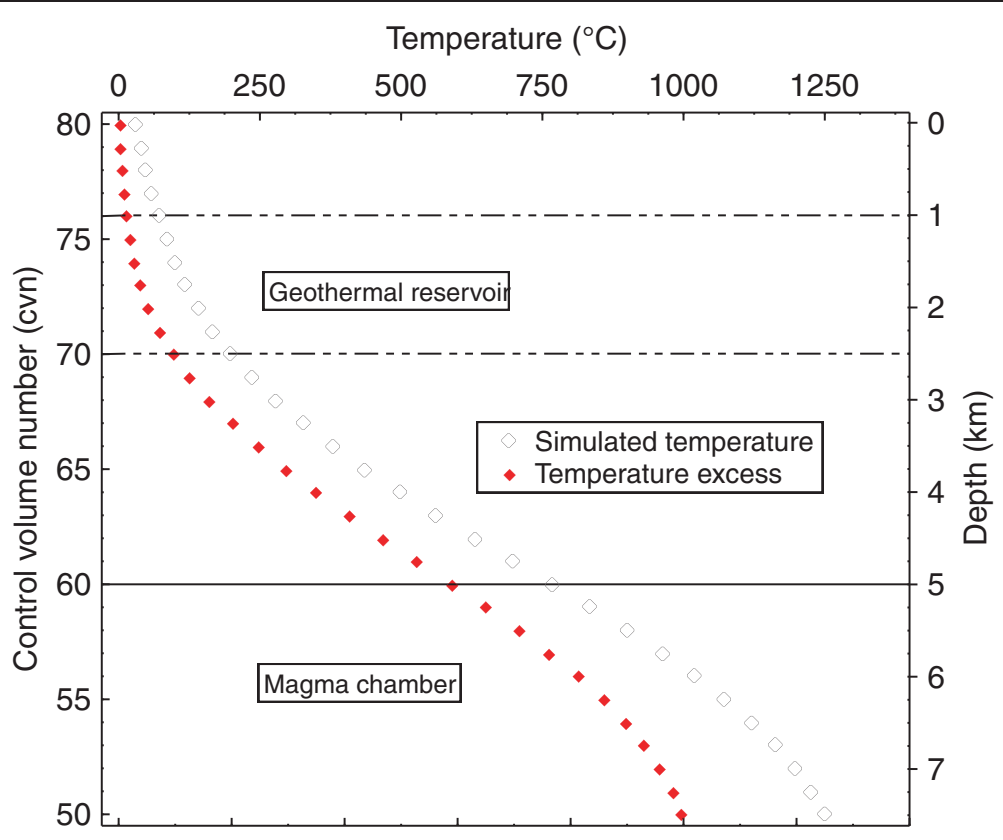

Figure 5 Simulated temperatures and temperature excess values. Actual simulated temperature (open diamonds) and temperature excess (difference between the simulated temperature and normal geothermal gradient temperature; filled diamonds) are reported for the model M55 (magma chamber at $5 \mathrm{~km}$ depth, $600 \mathrm{~km}^{3}$ volume, and emplacement time of the 100,000 years with $\delta t$ of 500 years).

was obtained for this equation, which is not as high as for Equations 1 to 16. In Equation 19, the coefficients for the dc terms are consistently much higher than the respective coefficients for the $V$ terms; for example, 169 for dc as compared to 0.069 for $V$, equivalent to a factor of about 2,400. The coefficients of quadratic and cubic terms are also higher for dc than for $V$ (Table 5). The final combined equation, therefore, clearly confirms that the chamber depth is more sensitive than the volume. From the energy point of view, geoscientists (in particular geologists, volcanologists, and geophysicists) are encouraged to better constrain the chamber depth than its volume. This recommendation is valid not only for geothermal areas but also for active volcanoes. We also note that although we have evaluated the thermal regime in terms of the centroid depth, the inference will not change had we used the top of the chamber depth, instead of the centroid depth.

\section{Preliminary three-dimensional thermal runs for a model of the Los Azufres geothermal field (LAGF)}

The main aim of simulating these six additional runs for the model M55; Table 2) was to assess the effects of discretization time and mesh size (Figure 6). Their influence was evaluated at three different locations (L1, L2, and L3; Figure 4). For the largest discretization time of 20 years, the geothermal reservoir showed simulated temperatures of about $160^{\circ} \mathrm{C}$ for mesh size of $0.20 \mathrm{~km}$ and $175^{\circ} \mathrm{C}$ for mesh size of $0.10 \mathrm{~km}$, whereas for 1 year, these temperatures were about $155^{\circ} \mathrm{C}$ and $160^{\circ} \mathrm{C}$, respectively. Even larger differences in simulated temperature were observed for the other two locations (see L2 and L3 in Figure 6). Thus, both parameters - discretization time and mesh size - exert 
Table 3 Cubic best-fit equations for the simulated thermal gradient in the geothermal reservoir as a function of the depth of the centroid of the magma chamber

\begin{tabular}{|c|c|c|c|c|c|}
\hline $\begin{array}{l}\text { Equation } \\
\quad \#\end{array}$ & $\begin{array}{l}\text { Depth of the top of magma } \\
\text { chamber } d(k m)\end{array}$ & $\begin{array}{l}\text { Centroid of the magma chamber } \\
\text { dc }(\mathrm{km})[\text { Model \#] }\end{array}$ & $\begin{array}{l}\text { Volume of the magma } \\
\text { chamber } V\left(\mathrm{~km}^{3}\right)\end{array}$ & $R^{2}$ & Equation $^{a}$ \\
\hline 1 & 5.0 to 9.0 & 7.0 to 11.0 [M1 to M9] & 300 & 0.999000 & $\delta T=(1668 \pm 96)-(498.9 \pm 32.6) \mathrm{dc}+(49.76 \pm 3.66) \times \mathrm{dc}^{2}-(1.653 \pm 0.135) \mathrm{dc} \mathrm{c}^{3}$ \\
\hline 2 & 5.0 to 9.0 & 7.25 to 11.25 [M10 to $\mathrm{M} 18]$ & 350 & 0.998993 & $\delta T=(1798 \pm 105)-(524.9 \pm 34.6) d c+(51.08 \pm 3.77) d c^{2}-(1.656 \pm 0.136) d c^{3}$ \\
\hline 3 & 5.0 to 9.0 & 7.5 to 11.5 [M19 to M27] & 400 & 0.998991 & $\delta T=(1933 \pm 114)-(551.1 \pm 36.5) d c+(52.35 \pm 3.88) d c^{2}-(1.657 \pm 0.136) d c^{3}$ \\
\hline 4 & 5.0 to 9.0 & 7.875 to 11.875 [M28 to M36] & 450 & 0.998990 & $\delta T=(2148 \pm 128)-(591.1 \pm 39.5) \mathrm{dc}+(54.22 \pm 4.04) \mathrm{dc}^{2}-(1.657 \pm 0.136) d c^{3}$ \\
\hline 5 & 5.0 to 9.0 & 8.25 to 12.75 [M37 to $M 45]$ & 500 & 0.998990 & $\delta T=(2377 \pm 143)-(632.5 \pm 42.6) d c+(56.09 \pm 4.19) d c^{2}-(1.657 \pm 0.136) d c^{3}$ \\
\hline 6 & 5.0 to 9.0 & 8.5 to 12.5 [M46 to M54] & 550 & 0.998990 & $\delta T=(2539 \pm 154)-(661 \pm 45) d c+(57.33 \pm 4.29) d c^{2}-(1.657 \pm 0.136) d c^{3}$ \\
\hline 7 & 5.0 to 9.0 & 8.875 to 12.875 [M55 to M63] & 600 & 0.998990 & $\delta T=(2795 \pm 172)-(705 \pm 48) d c+(59.2 \pm 4.4) d c^{2}-(1.657 \pm 0.136) d c^{3}$ \\
\hline
\end{tabular}

a The coefficients and their errors in the equations are rounded values according to the flexible rules put forth by Verma (2005). For Model \# see Table 2. 
Table 4 Cubic best-fit equations for the simulated thermal gradient in the geothermal reservoir as a function of the volume of the magma chamber

\begin{tabular}{|c|c|c|c|c|c|}
\hline Equation \# & $\begin{array}{l}\text { Depth of the top of } \\
\text { magma chamber } \\
(\mathrm{d}, \mathrm{km})\end{array}$ & $\begin{array}{l}\text { Centroid of the } \\
\text { magma chamber } \\
(\mathrm{dc}, \mathrm{km})\end{array}$ & $\begin{array}{c}\text { Volume of the magma } \\
\text { chamber }\left(V, \mathrm{~km}^{3}\right) \\
\text { [Model \#] }\end{array}$ & $R^{2}$ & Equation $^{a}$ \\
\hline 8 & 5.0 & 7.000 to 8.875 & $\begin{array}{l}300 \text { to } 600[\mathrm{M} 1,10,19,28,37, \\
46,55]\end{array}$ & 0.991220 & $\begin{array}{l}\delta T=(45.712 \pm 0.129)+\left(5.80 \times 10^{-3} \pm 0.90 \times 10^{-3}\right) V-\left(11.67 \times 10^{-3} \pm 2.05 \times 10^{-3}\right) V^{2}+(7.69 \times \\
\left.10^{-3} \pm 1.52 \times 10^{-3}\right) V^{3}\end{array}$ \\
\hline 9 & 5.5 & 7.500 to 9.375 & $\begin{array}{l}300 \text { to } 600[\mathrm{M} 2,11,20,29,38, \\
47,56]\end{array}$ & 0.988839 & $\begin{array}{l}\delta T=(26.113 \pm 0.044)+\left(1.87 \times 10^{-3} \pm 3.12 \times 10^{-4}\right) V-\left(37.6 \times 10^{-4} \pm 7.1 \times 10^{-4}\right) V^{2}+(24.9 \times \\
\left.10^{-4} \pm 5.2 \times 10^{-4}\right) V^{3}\end{array}$ \\
\hline 10 & 6.0 & 8.000 to 9.875 & $\begin{array}{l}300 \text { to } 600[\mathrm{M} 3,12,21,30,39 \\
\qquad 48,57]\end{array}$ & 0.986291 & $\begin{array}{l}\delta T=(13.7530 \pm 0.0139)+\left(55.2 \times 10^{-5} \pm 9.8 \times 10^{-5}\right) V-\left(11.14 \times 10^{-4} \pm 2.23 \times 10^{-4}\right) V^{2}+(7.42 \times \\
\left.10^{-4} \pm 1.65 \times 10^{-4}\right) V^{3}\end{array}$ \\
\hline 11 & 6.5 & 8.500 to 10.375 & $\begin{array}{l}300 \text { to } 600[\mathrm{M} 4,13,22,31,40, \\
49,58]\end{array}$ & 0.983621 & $\begin{array}{l}\delta T=\left(6.69010 \pm 4.03 \times 10^{-3}\right)+\left(15.04 \times 10^{-5} \pm 2.83 \times 10^{-5}\right) V-\left(30.5 \times 10^{-5} \pm 6.4 \times 10^{-5}\right) V^{2}+ \\
\left(20.4 \times 10^{-5} \pm 4.8 \times 10^{-5}\right) V^{3}\end{array}$ \\
\hline 12 & 7.0 & 9.000 to 10.875 & $\begin{array}{l}300 \text { to } 600[\mathrm{M} 5,14,23,32,41 \\
50,59]\end{array}$ & 0.980872 & $\begin{array}{l}\delta T=\left(3.00922 \pm 1.07 \times 10^{-3}\right)+\left(37.8 \times 10^{-6} \pm 7.5 \times 10^{-6}\right) V-\left(7.70 \times 10^{-5} \pm 1.70 \times 10^{-5}\right) V^{2}+ \\
\left(5.15 \times 10^{-5} \pm 1.26 \times 10^{-5}\right) V^{3}\end{array}$ \\
\hline 13 & 7.5 & 9.500 to 11.375 & $\begin{array}{l}300 \text { to } 600[\mathrm{M} 6,15,24,33,42, \\
51,60]\end{array}$ & 0.978078 & $\begin{array}{l}\delta T=\left(1.252520 \pm 2.59 \times 10^{-4}\right)+\left(8.80 \times 10^{-6} \pm 1.82 \times 10^{-6}\right) V-\left(17.96 \times 10^{-6} \pm 4.13 \times 10^{-6}\right) V^{2}+ \\
\left(12.06 \times 10^{-6} \pm 3.06 \times 10^{-6}\right) V^{3}\end{array}$ \\
\hline 14 & 8.0 & 10.000 to 11.875 & $\begin{array}{l}300 \text { to } 600[M 7,16,25,34,43 \\
52,61]\end{array}$ & 0.975271 & $\begin{array}{l}\delta T=\left(0.172276 \pm 1.19 \times 10^{-5}\right)+\left(37.8 \times 10^{-8} \pm 8.4 \times 10^{-8}\right) V-\left(7.75 \times 10^{-7} \pm 1.91 \times 10^{-7}\right) V^{2}+ \\
\left(5.22 \times 10^{-7} \pm 1.41 \times 10^{-7}\right) V^{3}\end{array}$ \\
\hline 15 & 8.5 & 10.500 to 12.375 & $\begin{array}{l}300 \text { to } 600[\mathrm{M} 8,17,26,35,44, \\
53,62]\end{array}$ & 0.972478 & $\begin{array}{l}\delta T=\left(0.172276 \pm 1.19 \times 10^{-5}\right)+\left(37.8 \times 10^{-8} \pm 8.4 \times 10^{-8}\right) V-\left(7.75 \times 10^{-7} \pm 1.91 \times 10^{-7}\right) V^{2}+ \\
\left(5.22 \times 10^{-7} \pm 1.41 \times 10^{-7}\right) V^{3}\end{array}$ \\
\hline 16 & 9.0 & 11.000 to 12.875 & $\begin{array}{l}300 \text { to } 600[\mathrm{M} 9,18,27,36,45 \\
54,63]\end{array}$ & 0.969720 & $\begin{array}{l}\delta T=\left(0.05697113 \pm 2.28 \times 10^{-6}\right)+\left(69.8 \times 10^{-9} \pm 1.6 \times 10^{-8}\right) V-\left(14.37 \times 10^{-8} \pm 3.64 \times 10^{-8}\right) V^{2}+ \\
\left(9.68 \times 10^{-8} \pm 2.69 \times 10^{-8}\right) V^{3}\end{array}$ \\
\hline
\end{tabular}


Table 5 Cubic best-fit equations for thermal gradient in the geothermal reservoir as a function of either chamber depth or volume, or both, from all 63 simulated models

\begin{tabular}{|c|c|c|c|c|c|}
\hline Equation \# & $\begin{array}{l}\text { Depth of the top of magma } \\
\text { chamber }(\mathrm{d}, \mathrm{km})\end{array}$ & $\begin{array}{l}\text { Centroid of the magma } \\
\text { chamber }(\mathrm{dc}, \mathrm{km})\end{array}$ & $\begin{array}{l}\text { Volume of the magma } \\
\text { chamber }\left(V, \mathrm{~km}^{3}\right)\end{array}$ & $R^{2}$ & Equation $^{\mathrm{a}}$ \\
\hline 17 & 5.0 to 9.0 & 7.000 to 12.875 & -—-—-—-— & 0.691799 & $\delta T=(299 \pm 289)-(50 \pm 89) d c+(2.0 \pm 9.1) d c^{2}-(0.009 \pm 0.306) d c^{3}$ \\
\hline 18 & 一一一一一一 & -——-—- & 300 to 600 & 0.000000 & \multirow{2}{*}{$\begin{aligned} \delta T= & (11 \pm 239)+(1 \pm 1680) V-(2 \pm 3820) V^{2}+(1 \pm 2820) V^{3} \\
\delta T= & (677 \pm 238)-(169 \pm 68) \mathrm{dc}+(13.9 \pm 7.0) \mathrm{dc}^{2}-(0.392 \pm 0.234) \mathrm{dc}^{3} \\
& -(0.069 \pm 0.69) V+(0.37 \pm 1.58) V^{2}-(0.31 \pm 1.17) V^{3}\end{aligned}$} \\
\hline 19 & 5.0 to 9.0 & 7.000 to 12.875 & 300 to 600 & 0.838748 & \\
\hline
\end{tabular}

${ }^{\mathrm{a}}$ The coefficients and their errors in the equations are rounded values according to the flexible rules put forth by Verma (2005). 


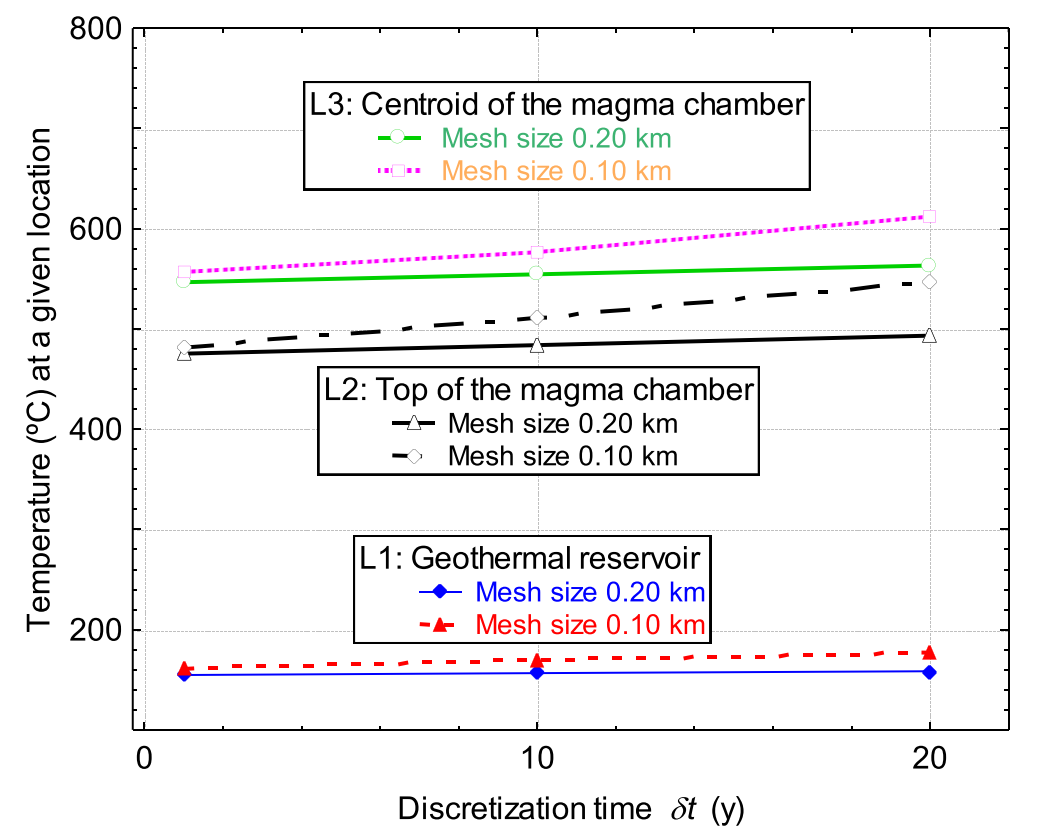

Figure 6 Simulated temperatures at three locations (L1, L2, and L3). Temperatures are reported as a function of discretization time and mesh size for the model M55 of the Los Azufres geothermal field (LAGF).

significant influence in the estimated temperatures. These results are consistent with those recently simulated by Verma and Gómez-Arias (2013b) for the LHGF and LPGF.

The simulated 'present-day' temperatures of about $160^{\circ} \mathrm{C}$ at the middle of the geothermal reservoir (for $\delta t=1$ year and mesh size $=0.10 \mathrm{~km}$ ) are generally consistent with the actually measured temperatures (generally $120^{\circ} \mathrm{C}$ to $250^{\circ} \mathrm{C}$ ) in the LAGF (Verma and Andaverde 1996). The simulated runs for the LAGF can be improved in the future by incorporating all geological processes, such as magma evolution (fractional crystallization, assimilation, and magma mixing), convection in the magma chamber and geothermal reservoir, and heat generation from radioactive elements. Similarly, the smallest possible discretization time and mesh size will be used.

\section{Conclusions}

The first three-dimensional thermal simulation study carried out for the Los Azufres geothermal field (LAGF) provided 19 best-fit cubic equations from 63 simulations to understand the influence of the depth and volume of the underlying magma chamber. The coefficients of the centroid depth terms were much higher than those of the volume terms, implying that the centroid depth is much more sensitive than the chamber volume. The chamber depth should therefore be better constrained than the chamber volume, not only in geothermal areas but also in active volcanoes. Preliminary thermal modeling of the LAGF also shows that the present-day mean simulated temperatures in the geothermal reservoir are around $160^{\circ} \mathrm{C}$. 


\section{Authors' contributions}

Both authors conceived the main idea of evaluating the simulation parameters. EGA did the computational work and preparation of tables and figures. SPV wrote the paper. Both authors read and improved the final version of the manuscript.

\section{Acknowledgements}

The second author (EGA) is grateful to Conacyt (Mexico) for granting him a post-doctoral fellowship. Computing facilities were those from the DGAPA-UNAM PAPIIT project IN104813. We are grateful to Alfredo Quiroz-Ruiz for help in computer maintenance. We also thank three anonymous reviewers of the journal for their high appreciation of our work and for indicating minor errors in our two earlier versions, which were corrected in the final paper.

\section{Author details}

'Departamento de Sistemas Energéticos, Instituto de Energías Renovables, Universidad Nacional Autónoma de México, Privada Xochicalco s/n, Centro, Temixco, Morelos 62580, Mexico. ${ }^{2}$ Centro de Investigación en Ingeniería y Ciencias Aplicadas, Universidad Autónoma del Estado de Morelos, Av. Universidad 1001, Chamilpa, Cuernavaca, Morelos 62209, Mexico.

Received: 24 July 2013 Accepted: 24 September 2013

Published: 5 November 2013

\section{References}

Bevington PR, Robinson DK (2003) Data reduction and error analysis for the physical sciences. Mc Graw Hill, Boston Campos-Enríquez JO, Domínguez-Méndez F, Lozada-Zumaeta M, Morales-Rodríguez HF, Andaverde-Arredondo JA (2005) Application of the Gauss theorem to the study of silicic calderas: the calderas of La Primavera, Los Azufres, and Los Humeros (Mexico). J Volcanol Geotherm Res 147:39-67

Cathelineau M, Oliver R, Nieva D (1987) Geochemistry of volcanic series of the Los Azufres geothermal field (Mexico). Geofís Int 26:273-290

Contreras LE, Domínguez AB, Iglesias RE, García GA, Huitrón ER (1988) Compendio de resultados de mediciones petrofísicas en núcleos de perforación del campo geotérmico Los Azufres. Geotermia 4:79-105

Cruz-Huicochea R, Verma SP (2013) New critical values for F and their use in the ANOVA and Fisher's F tests for evaluating geochemical reference material granite G-2 from USA and igneous rocks from the Eastern Alkaline Province of Mexico. J Iberian Geology 39:13-30

Dobson PF, Mahood GA (1985) Volcanic stratigraphy of the Los Azufres geothermal area, Mexico. J Volcanol Geotherm Res 25:273-287

Ebdon D (1988) Statistics in Geography. Basic Blackwell, Oxford

Guerrero-Martínez FJ, Verma SP (2013) Three dimensional temperature simulation from cooling of two magma chambers in the Las Tres Vírgenes geothermal field, Baja California Sur, Mexico. Energy 52:110-118

Pandarinath K (2011) Solute geothermometry of springs and wells of the Los Azufres and Las Tres Virgenes geothermal fields, Mexico. Int Geol Rev 53:1032-1058

Pandarinath K, Dulski P, Torres-Alvarado IS, Verma SP (2008) Element mobility during the hydrothermal alteration of rhyolitic rocks of the Los Azufres geothermal field, Mexico. Geothermics 37:53-72

Pradal E, Robin C (1994) Long-lived magmatic phases at Los Azufres volcanic center, Mexico. J Volcanol Geotherm Res 63:201-215

Verma SP (1985) On the magma chamber characteristics as inferred from surface geology and geochemistry: examples from Mexican geothermal areas. Phys Earth Planet Inter 41:207-214

Verma SP (2005) Estadística básica para el manejo de datos experimentales: aplicación en la Geoquímica (Geoquimiometría). UNAM, México, DF

Verma SP, Andaverde J (1996) Temperature distributions from cooling of a magma chamber in Los Azufres geothermal field, Michoacán, Mexico. Geofís Int 35:105-113

Verma SP, Andaverde J (2007) Coupling of thermal and chemical simulations in a 3-D integrated magma chamberreservoir model: a new geothermal energy research frontier. In: Ueckermann HI (ed) Geothermal Energy Research Trends. Nova Science Publishers, Inc., New York, pp 149-189

Verma SP, Cruz-Huicochea R (2013) Alternative approach for precise and accurate Student's critical values in geosciences and application in geosciences. J Iberian Geology 39:31-56

Verma SP, Gómez-Arias E (2013a) Effect of discretization time and mesh size in three-dimensional temperature field simulation of geothermal fields and application to the La Primavera geothermal field, Mexico. Geothemics. In press

Verma SP, Gómez-Arias E (2013b) Three-dimensional temperature field simulation of magma chamber in the Los Humeros geothermal field, Puebla, Mexico. Appl Therm Eng 52:512-515

Verma SP, Torres-Alvarado IS, Satir M, Dobson PF (2005) Hydrothermal alteration effects in geochemistry and Sr, Nd, Pb, and O isotopes of magmas from the Los Azufres geothermal field (Mexico): a statistical approach. Geochem J 39:141-163

Verma SP, Gómez-Arias E, Andaverde J (2011) Thermal sensitivity analysis of emplacement of the magma chamber in Los Humeros caldera, Puebla, Mexico. Int Geol Rev 53:905-924

Verma SP, Arredondo-Parra UC, Andaverde J, Gómez-Arias E, Guerrero-Martínez FJ (2012) Three-dimensional temperature field simulation of a cooling of a magma chamber, La Primavera caldera, Jalisco, Mexico. Int Geol Rev 54:833-843

Verma SP, Cruz-Huicochea R, Díaz-González L (2013) Univariate data analysis system: deciphering mean compositions of island and continental arc magmas, and influence of underlying crust. Int Geol Rev 55:1922-1940

doi:10.1186/2195-9706-1-5

Cite this article as: Verma and Gómez-Arias: Three-dimensional thermal sensitivity analysis of cooling of a magma chamber in the Los Azufres geothermal field, Michoacán, Mexico. Geothermal Energy 2013 1:5. 